\title{
KUANTITAS ANAKAN KULTUR SEMUT RANGRANG, Oecophylla smaragdina, SECARA ARTIFISIAL DENGAN MENGGUNAKAN BEBERAPA JENIS PAKAN BERBEDA
}

\author{
LINTANG DIANING RATRI, EDI BASUKI, DARSONO
}

Fakultas Biologi, Universitas Jenderal Soedirman, Jalan dr. Suparno 63 Purwokerto 53122

\section{A B S T R A C T}

Oecophylla smaragdina or weaver ants is social insect that has an important role in the ecosystem. One of its main function is as a biological control agent in agriculture. The use of weaver ants in an effort to develop a biocontrol continues and increases, this has caused the significant decrease of the natural population of 0 . smaragdina. Therefore, the weaver ants rearing is needed to maintain its existence in natural habitat without excessive exploitation. The purpose of this study were to determine the effect of different types of feed i.e. snails, earthworms, and okara (tofu by-product) in the production of weaver ants kroto; and to determine the different of treatments of feeds provided to the production quantity of weaver ants kroto. The experimental method used in this study with a completely randomized design. Treatment was given by different protein sources feeding i.e. snails (Pomacea canaliculata), earthworm (Lumbricus rubellus), and okara. Five replicates were appliead for each treatment. Earthworms fed ants produced highest number of kroto with total of 1,030 individuals and weight 87.4 gram in total. Snails fed ants produced 866 individuals and weight 73.1 gram. Okara fed ants produced 543 individuals and weight 45.9 gram.

KEY WORDS: Oecophylla smaragdina, waeaver ants, kroto

Penulis korespondensi: LINTANG DIANING RATRI | email: lintangdratri@gmail.com

\section{PEN D A H U L UAN}

Semut merupakan hewan avertebrata yang memiliki peranan penting berdasarkan keanekaragaman jenis, sifat biologi dan ekologinya. Hal ini didukung oleh beberapa sifat yang dimiliki semut, yaitu hidup di berbagai habitat, mempunyai toleransi yang sempit terhadap perubahan lingkungan, biomassa dominan, mempunyai sifat penting dalam ekosistem, mudah dikoleksi serta secara taksonomi relatif maju (Andersen, 1997 dan Agosti et al., 2000).

Salah satu jenis semut yang cukup dikenal adalah semut rangrang (Oecophylla smaragdina). Semut rangrang adalah serangga sosial yang mempunyai peranan penting dalam ekosistem, yaitu sebagai predator bagi berbagai serangga (Mele, 2008). Semut rangrang disebut juga sebagai weaver ant yang memiliki cara hidup khas yaitu merajut daun-daun pada pohon untuk membuat sarang (Mele \& Nguyen, 2007). Semut ini sangat agesif, berlimpah dan menjaga kawasannya dari spesies lain. Semut rangrang memiliki posisi penting secara ekologi di hutan, perkebunan kakao dan lingkungan berhutan lain yang dihuni, selain itu semut rangrang juga telah menjadi objek dari semakin banyaknya studi lapangan (Holldobler \& Wilson, 1977).

Peranan utama semut rangrang adalah sebagai salah satu agen pengendali hayati dalam dunia pertanian yang memiliki beberapa manfaat. Menurut Offenberg et al., (2013), dalam teknis budidaya pertanian, semut rangrang telah digunakan dalam proses pengendalian hayati di Negara Australia yang mampu mengendalikan ulat pada buah mangga dan jambu mete. Sesuai dengan pernyataan Juriyanto (2013), semut rangrang dapat mengganggu, menghalangi atau memangsa berbagai jenis hama seperti kepik hijau, ulat pemakan daun, dan serangga pemakan buah.

Populasi Oecophylla smaragdina mengalami penurunan yang cukup signifikan. Tahun 2009 hingga Januari 2012 penurunannya sangat tajam, yaitu berkisar antara $50 \%$ dari jumlah yang ada di alam (Harlan, 2006). Hal tersebut dikarenakan populasi semut rangrang sering dijadikan objek perburuan bahkan dieksploitasi secara besar-besaran. Telur, larva dan pupa (kroto) adalah yang umumnya sering dimanfaatkan. Kroto biasanya digunakan sebagai pakan burung, umpan memancing ikan, serta untuk pakan ayam karena diyakini dapat mempercepat baik pertumbuhan bulu maupun produksi daging (Cesard, 2004). Kroto menjadi salah satu bahan pakan yang digemari karena kandungan proteinnya yang tinggi. Bahkan di beberapa negara seperti Thailand dan Filipina tidak membudidayakan kroto untuk pakan burung atau ikan saja, tetapi juga sebagai bahan pangan bagi manusia juga. Bagi mereka, kroto memiliki cita rasa yang lembut layaknya krim (Prayoga, 2013).

Kroto yang tersedia di pasaran berasal dari alam, sedangkan alam tidak selalu mampu menyediakan kroto apalagi di saat musim penghujan. Di sisi lain permintaan kroto terus mengalami peningkatan. Berdasarkan hasil survei Kroto Research Institute pada tahun 2008-2013 menyebutkan permintaan pasar di daerah jakarta dan sekitarnya mencapai ratusan kilogram per hari (Prayoga, 2014). Keberadaan kroto semakin lama semakin langka, hal ini tidak bisa dibiarkan terus-menerus. Budidaya kroto dipandang sebagai jalan keluar untuk mendapatkan kroto dalam jumlah banyak dan kontinyu (Kroto Research Institute, 2012). Selain untuk memenuhi permintaan pasar, budidaya semut 
rangrang juga diperlukan untuk keseimbangan ekosistem di alam.

Menurut Prasetyo (2015), budidaya semut rangrang memiliki beberapa kelebihan dibandingkan dengan pencarian kroto dari alam. Kelebihan dari proses budidaya ialah hasil kroto yang didapatkan sudah dapat diprediksi sebelumnya, pemenuhan kroto tidak tergantung kondisi cuaca/alam, mudah cara pengelolaannya, hasil panen kroto lebih bersih dan jika pemberian pakan dilakukan dengan tepat akan menghasilkan kroto dengan kualitas yang baik. Beberapa kelebihan yang didapatkan juga tidak terlepas dari adanya hambatan pada saat melakukan proses budidaya semut rangrang. Ada beberapa faktor yang yang harus dipenuhi oleh peternak dalam melakukan proses budidaya semut rangrang, yaitu berkaitan dengan kondisi lingkungan kandang budidaya, jenis pakan semut rangrang dan minuman. Pemberian jenis pakan merupakan hal yang sangat berpengaruh terhadap produktivitas kroto.

Menurut Prayoga (2013), pakan merupakan komponen yang sangat penting sebagai sumber nutrisi bagi ternak semut rangrang untuk berproduksi. Zat gizi utama yang diperlukan oleh semut rangrang sama dengan hewan ternak lain, yakni protein dan karbohidrat (gula). Protein merupakan salah satu zat makanan yang sangat dibutuhkan oleh semut terutama untuk tujuan produksi, karena protein ini setelah dimetabolismekan dalam tubuh, dicerna dan diserap, maka akan didapatkan hasil akhir yang merupakan hasil produksi (output) dari ternak (Mele \& Cuc, 2007). Peranan protein sangat penting dalam tubuh ternak, tidak saja sebagai penentu kualitas produksi, tetapi juga untuk keperluan hidup pokok dan aktivitasnya. Kebutuhan protein disesuaikan dengan kemampuan ternak dalam mengkonsumsi protein serta mempertimbangkan keseimbangan zat-zat makanan karena mempengaruhi kecepatan pertumbuhan (Scott et al., 1992).

Berdasarkan penelitian Rizqytiasti (2015), yang memberikan pakan protein terhadap semut rangrang berupa keong mas (Pomacea canaliculata), cacing tanah (Lumbricus rubellus), dan ampas tahu menunjukkan hasil bahwa pakan dari cacing tanah dapat menghasilkan biomassa semut rangrang yang lebih tinggi dibandingkan dengan semut yang diberi pakan keong mas dan limbah tahu, namun sejauh ini penelitian tersebut belum menunjukkan jumlah anakan kroto yang dihasilkan. Oleh karena itu, diperlukan penelitian lebih lanjut manakah dari ketiga jenis pakan tersebut yang menunjukkan jumlah atau kuantitas kroto semut rangrang yang cukup signifikan. Tujuan penelitian ini adalah mengetahui pengaruh pemberian jenis pakan yang berbeda yaitu keong mas, cacing tanah, dan ampas tahu terhadap produksi kroto semut rangrang (O. smaragdina) dan mengetahui perlakuan pemberian jenis pakan berbeda yang menunjukkan hasil kuantitas produk kroto semut rangrang (O. smaragdina) yang dibudidaya secara artifisial. Hasil penelitian ini diharapkan dapat memberikan informasi ilmiah terkait pemberian jenis pakan berbeda terhadap produksi kroto semut rangrang dan kuantitas paling baik pada kroto semut rangrang yang dibudidaya secara artifisial.

\section{MET O D E}

Alat-alat yang digunakan yaitu rak kayu, toples plastik, gunting ranting atau gunting dahan, sarung tangan karet, pinset, hand counter, ember plastik, lemari es, timbangan analitik, termometer, termohigrometer, pipet ukur, dan gelas ukur. Bahan-bahan yang digunakan adalah semut rangrang (Oecophylla smaragdina), keong mas (Pomacea canaliculata), cacing tanah (Lumbricus rubellus), ampas tahu, air, dan gula. Penelitian dilakukan di daerah Karangwangkal, Purwokerto Utara, Banyumas selama bulan Maret-Juli 2016.

Penelitian ini menggunakan metode eksperimental dengan rancangan percobaan yang digunakan adalah Rancangan Acak Lengkap (RAL). Perlakuan terdiri atas pemberian pakan yaitu berupa keong mas, cacing tanah, dan ampas tahu. Tiap perlakuan diulang sebanyak lima kali.

Variabel bebas dari penelitian ini adalah pemberian jenis pakan yang berbeda yaitu keong mas, cacing tanah, dan ampas tahu dan variabel tergantung dalam penelitian ini adalah produksi kroto semut rangrang yang dibudidayakan secara artifisial selama 25 hari. Parameter utama yang diamati adalah selisih jumlah (kuantitas) anakan baru yang dihasilkan dan parameter pendukungnya adalah selisih antara berat total (biomassa) sebelum dengan sesudah dibudidayakan secara artifisial dengan jenis pakan yang berbeda, sehingga hasil yang diperoleh merupakan berat kroto.

Pakan sumber protein yang digunakan ialah keong mas, cacing tanah, dan ampas tahu. Masing-masing pakan dicacah kecil disesuaikan dengan kemampuan semut untuk mencerna makanannya. Pakan tersebut diberikan sebanyak 2 gram tiap harinya, sedangkan untuk pakan sumber karbohidrat diguanakn larutan air gula yang diberikan sebanyak $10 \mathrm{ml}$ setiap harinya.

Pembibitan dilakukan dengan mengambil koloni semut rangrang dari alam. Toples plastik sebagai sarang semut rangrang diletakkan pada meja/rak. Toples tersebut dilubangi sebagai jalan aktivitas semut. Semut rangrang yang sudah didapatkan kemudian dipindahkan ke dalam meja/rak yang sudah disiapkan dengan makanan dan air gula dalam nampan kecil.dengan sendirinya semut rangrang akan masuk ke dalam toples yang akan digunakan sebagai sarang baru (Gambar 1 dan 2).

Budidaya semut rangrang dilakukan secara artifisial menggunakan metode budidaya yang modern dengan menggunakan toples plastik sebagai media sarang baru dan diberi jenis pakan yang berbeda yaitu keong mas, cacing tanah, dan ampas tahu, serta diberi larutan air gula sebagai sumber karbohidrat. Pemberian jenis pakan yang berbeda dimaksudkan untuk mengetahui produksi kroto semut rangrang dengan menghitung selisih bobot awal koloni dan bobot akhir koloni setelah diberi perlakuan. Koloni satu dengan yang lain disamakan jumlahnya yaitu 1 semut ratu dan 750 semut prajurit. Perhitungan koloni tersebut menggunakan teknik pendinginan di dalam lemari es. Selanjutnya, koloni semut rangrang tersebut diberi pakan yang berbeda yaitu keong mas, cacing tanah, dan ampas tahu sebanyak 2 gram dan air gula dengan perbandingan 1:1 sebanyak $10 \mathrm{ml}$ selama 25 hari. 
Kroto dapat dipanen setelah 25 hari dibudidayakan dengan mengetahui telur semut dalam toples sudah terlihat penuh. Setelah dipanen, dihitung jumlah anakan baru dan toples yang digunakan sebagai sarang semut ditimbang kembali sebagai berat akhir. Selisih antara berat awal (biomassa) dan berat akhir setelah diberi perlakuan merupakan berat kroto yang dihasilkan.

Data yang diperoleh berupa data hasil produksi jumlah dan berat kroto yang kemudian dianalisis menggunakan analisis ragam (uji F) pada tingkat kepercayaan 95\%-99\%. Perlakuan yang berpengaruh nyata/sangat nyata terhadap jumlah dan berat kroto dilanjutkan dengan uji Beda Nyata Terkecil (BNT), dengan tingkat kesalahan 1\%-5\%.

\section{HASIL DAN PEMBAHASAN}

Setelah dibudidayakan selama 25 hari didapatkan hasil bahwa semut rangrang yang diberi pakan cacing tanah menghasilkan kroto paling banyak yaitu 1.030 individu dibandingkan dengan yang diberi pakan keong mas, dan yang diberi pakan ampas tahu menghasilkan kroto dengan jumlah paling sedikit yaitu 543 individu. Hasil disajikan pada Tabel 1.

Tabel 1. Produksi Jumlah Kroto (Individu) Semut Rangrang yang Dibudidaya dengan Pakan Sumber Protein Berbeda

\begin{tabular}{llrrrrrrr}
\hline \multirow{2}{*}{ No } & \multirow{2}{*}{ Perlakuan } & \multicolumn{9}{c}{ Ulangan } & \multirow{2}{*}{ Total } & \multirow{2}{*}{ Rerata } \\
\cline { 3 - 8 } & $\mathbf{1}$ & $\mathbf{2}$ & $\mathbf{3}$ & $\mathbf{4}$ & $\mathbf{5}$ & & \\
\hline 1 & Keong Mas & 195 & 130 & 189 & 179 & 173 & 866 & 173 \\
2 & Cacing Tanah & 235 & 183 & 211 & 222 & 179 & 1030 & 206 \\
3 & Ampas Tahu & 85 & 103 & 144 & 97 & 114 & 543 & 108 \\
& Total & & & & & & $\mathbf{2 . 4 3 9}$ & $\mathbf{1 6 2}$ \\
\hline
\end{tabular}

Sementara untuk hasil berat kroto didapatkan bahwa semut rangrang yang diberi pakan cacing tanah menghasilkan berat massa total 87,4 gr dan memiliki rata-rata $17,48 \mathrm{gr}$. Semut rangrang yang diberi perlakuan keong mas menghasilkan berat massa total kroto sebanyak 73,1 gr dan memiliki ratarata 14,62 gr, sedangkan yang diberi pakan ampas tahu menghasilkan berat massa kroto yang paling rendah dibanding dengan perlakuan lainnya yaitu 45,9 gr dengan rata-rata 9,18 gr (Tabel 2). Ketiga pakan tersebut dapat membantu pertumbuhan semut rangrang, hal ini dapat dilihat dari kenaikan bobot sebelum dan sesudah diberi perlakuan. Kenaikan bobot tersebut dikarenakan ketiga jenis pakan yang digunakan merupakan sumber protein. Protein dibutuhkan serangga untuk kebutuhan strukturalnya, sebagai enzim, reseptor, serta untuk kebutuhan transport dan penyimpanan (Chapman, 1998).

Tabel 2. Produksi Berat Kroto (gr) Semut Rangrang yang Dibudidaya dengan Pakan Sumber Protein Berbeda

\begin{tabular}{llrrrrrrr}
\hline \multirow{2}{*}{ No } & \multirow{2}{*}{ Perlakuan } & \multicolumn{4}{c}{ Ulangan } & \multirow{2}{*}{ Total } & \multirow{2}{*}{ Rerata } \\
\cline { 2 - 6 } & & $\mathbf{1}$ & $\mathbf{2}$ & $\mathbf{3}$ & $\mathbf{4}$ & $\mathbf{5}$ & & \\
\hline 1 & Keong Mas & 16,4 & 11,1 & 15,9 & 15,1 & 14,6 & 73,1 & 14.62 \\
2 & Cacing Tanah & 20,2 & 15,4 & 18,0 & 18,9 & 15,1 & 87,4 & 17.48 \\
3 & Ampas Tahu & 7,2 & 8,7 & 12,1 & 8,2 & 9,7 & 45,9 & 9.18 \\
& Total & & & & & & $\mathbf{2 0 6 , 4}$ & $\mathbf{1 3 , 7 6}$ \\
\hline
\end{tabular}

Data yang telah diperoleh baik data hasil produksi kroto (individu) maupun berat kroto kemudian dianalisis dengan analisis ragam (Uji F) dengan tingkat kepercayaan 99\% dan 95\% untuk mengetahui pengaruh pemberian sumber protein terhadap produksi kroto dari semut rangrang. Hasil analisis ragam menunjukkan bahwa pemberian jenis pakan berbeda pada penelitian memberikan pengaruh yang sangat nyata terhadap kroto yang diproduksi. Data kemudian, dianalisis lebih lanjut menggunakan uji beda nyata terkecil (BNT) yang disajikan pada Tabel 3 dan Tabel 4.

Tabel 3. Uji Beda Nyata Terkecil (BNT) Produksi Jumlah Kroto (Individu) Semut Rangrang yang Dibudidaya dengan Pakan Sumber Protein Berbeda pada Tingkat Kesalahan 5\%

\begin{tabular}{llc}
\hline No & \multicolumn{1}{c}{ Perlakuan } & $\begin{array}{c}\text { Rerata Produksi Kroto } \\
\text { yang Dihasilkan (Individu) }\end{array}$ \\
\hline 1 & Keong Mas & $173.2 \mathrm{a}$ \\
2 & Cacing Tanah & $206.0 \mathrm{a}$ \\
3 & Ampas Tahu & $108.6 \mathrm{~b}$ \\
\hline
\end{tabular}

Keterangan: Angka rata-rata yang didampingi huruf kecil yang sama menunjukkan tidak berbeda nyata

Tabel 4. Uji Beda Nyata Terkecil (BNT) Produksi Berat Kroto (gr) Semut Rangrang yang Dibudidaya dengan Pakan Protein Berbeda pada Tingkat Kesalahan 5\%

\begin{tabular}{llc}
\hline No & Perlakuan & $\begin{array}{c}\text { Rerata Berat Kroto } \\
\text { yang Dihasilkan (gram) }\end{array}$ \\
\hline 1 & Keong Mas & $14.62 \mathrm{~b}$ \\
2 & Cacing Tanah & $17.48 \mathrm{a}$ \\
3 & Ampas Tahu & $9.18 \mathrm{c}$ \\
\hline
\end{tabular}

Hasil uji BNT pada produksi jumlah (individu) kroto menunjukkan bahwa semut rangrang yang diberi pakan keong mas dan cacing tanah menunjukkan hasil yang tidak berbeda nyata terhadap produksi jumlah dan berat kroto yang dihasilkan, sedangkan perlakuan menggunakan pakan berupa ampas tahu menunjukkan hasil yang berbeda nyata terhadap dua perlakuan yang lain. Hasil uji BNT pada produksi berat kroto (gr) menunjukkan bahwa semut rangrang yang masing-masing diberi pakan keong mas, cacing tanah dan ampas tahu menunjukkan hasil berbeda nyata terhadap produksi berat kroto yang dihasilkan. Hasil produksi kroto yang berbeda dapat disebabkan karena nilai gizi yang terkandung di dalam pakan hewan ternak (Offenberg \& Wiwatwitaya, 2010).

Salah satu faktor yang menyebabkan adanya perbedaan dari hasil produksi (individu) dan berat kroto yang dihasilkan adalah daya cerna terhadap pakan yang diberikan. Keong mas dan cacing tanah merupakan pakan dengan sumber protein hewani, sedangkan ampas tahu merupakan pakan dengan sumber protein nabati. Protein nabati mempunyai derajat cerna yang rendah karena proteinnya terletak dalam sel yang berdinding selulosa sementara enzim pencernaan pada semut tidak dapat menghidrolisis selulosa. Ampas tahu jika dilihat dari komposisi kimianya dapat digunakan sebagai salah satu sumber protein, tetapi ampas tahu juga memiliki kelemahan sebagai bahan pakan yaitu kandungan serat kasar dan air yang tinggi (Duldjaman, 2005). Kandungan serat kasar yang tinggi menyulitkan sistem pencernaan semut rangrang untuk mencerna bahan pakan tersebut, karena semut rangrang tidak memiliki enzim 
pencernaan untuk memecah selulosa yang terdapat dalam ampas tahu. Sehingga dalam penelitian ini, semut rangrang yang diberi pakan protein berupa ampas tahu memiliki produktivitas yang rendah dalam menghasilkan kroto.

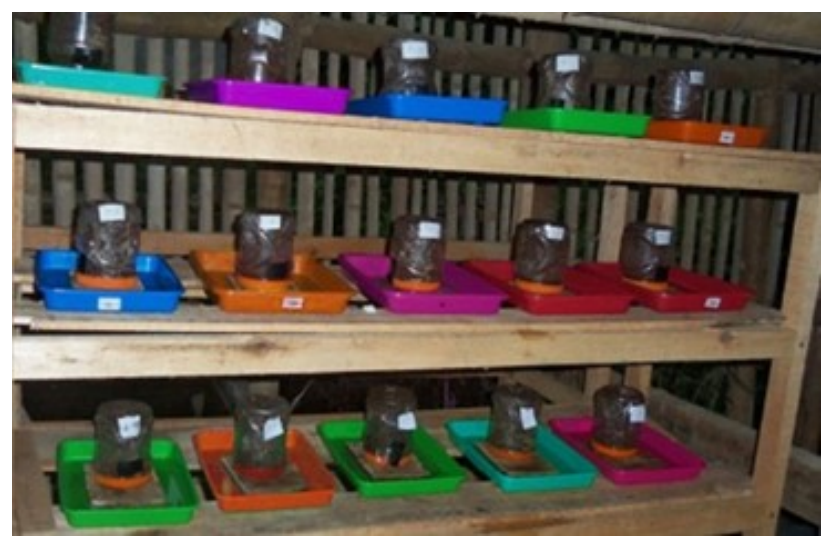

Gambar 1. Pemeliharaan Semut Rangrang Selama 25 Hari

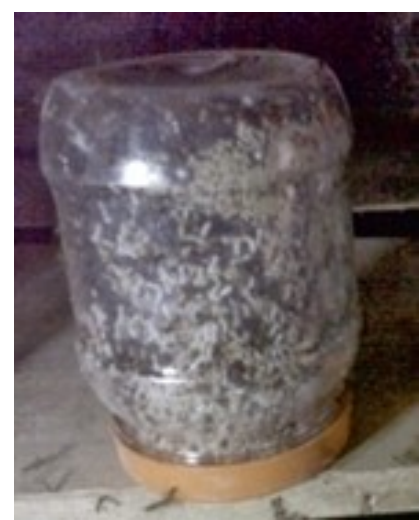

Gambar 2. Toples yang berisi kroto dengan diberi pakan cacing tanah

Menurut Salle (1973), semut belum memiliki enzim khusus untuk membantu memecahkan selulosa. Hal inilah yang menyebabkan semut rangrang sulit untuk mencerna dan memanfaatkan gizi yang terkandung dalam ampas tahu. Semut bersimbiosis dengan bakteri di dalam saluran pencernaannya untuk membantu mencerna sumber protein hewani maupun sumber protein nabati. Salah satu bakteri dari famili Bacillaceae dalam jumlah sedikit yang memiliki fungsi untuk mencerna jenis makanan semut berupa tumbuhan atau bagian tumbuhan yang kaya akan bahan-bahan karbohidrat kompleks seperti selulosa. Walaupun semut mampu mencerna ampas tahu, namun tidak seefektif seperti semut mencerna keong mas dan cacing tanah.

Keong mas (Pomacea canaliculata) merupakan hewan mollusca yang siklus hidupnya pendek, bereproduksi cepat karena bersifat hermaprodit. Keong mas cukup potensial sebagai sumber protein pakan ternak, karena kandungan protein yang dimiliki keong mas mencapai 51\%, lemak 13,61\%, serat 6,09\% dan abu 24\% (Anderson \& Richardson, 2004). Keunggulan lain yang dimiliki keong mas ialah memiliki gizi tinggi, mudah didapatkan, dan relatif terjangkau. Penggunaan cacing tanah sebagai pakan semut rangrang belum banyak dilakukan. Cacing tanah (Lumbricus rubellus) tergolong ke dalam hewan avertebrata sehingga sering disebut sebagai binatang lunak (Palungkun, 1999). Lunaknya tubuh cacing tanah memudahkan semut rangrang untuk menggigit dan menghisap cairan tubuh cacing tersebut, sehingga dapat diamati sisa tubuh cacing yang menyusut dan kering. Hal ini sesuai dengan Prayoga (2013) yang menggunakan ulat Hongkong sebagai pakan semut.

Selain membutuhkan protein, semut rangrang juga membutuhkan makanan tambahan berupa karbohidrat. Pada dasarnya di alam semut mendapatkan sumber karbohidrat berupa embun madu atau nektar. Pada penelitian ini sumber karbohidrat yang digunakan berupa cairan gula sebanyak $10 \mathrm{ml}$ per hari dan masih terdapat banyak sisa. Sesuai penyataan Falahudin (2012), semut rangrang tidak membutuhkan karbohidrat dalam jumlah yang banyak karena karbohidrat hanya diperlukan sebagai energi tambahan pada saat pembuatan sarang.

Faktor lingkungan juga sangat berpengaruh bagi keberhasilan produksi kroto yang tinggi. Ratu mulai bertelur dalam sarang dengan suhu $23-27{ }^{\circ} \mathrm{C}$ dan intensitas cahaya sekitar $0,01-0,06 \mathrm{~lm} / \mathrm{m}^{2}$. Suhu juga mempengaruhi perkembangan telur menjadi larva. Pada suhu $30{ }^{\circ} \mathrm{C}$, telur akan berubah menjadi larva dalam jangka waktu sekitar 8 hari (Suhara, 2009). Pada penelitian ini pengukuran temperatur dan kelembaban dilakukan 3 hari sekali pada pukul 06.00, 12.00, dan 18.00.

Menurut Rahman (2015), semut rangrang menyukai lingkungan dengan suhu antara $26-34{ }^{\circ} \mathrm{C}$ dan kelembaban relatif antara 62-92\%. Berdasarkan hasil pengamatan suhu lingkungan dan suhu di dalam toples selama penelitian berkisar antara $26-33{ }^{\circ} \mathrm{C}$ dan hasil pengamatan kelembaban lingkungan selama penelitian berkisar antara 48-63\%.

Aktivitas pencarian pakan dipengaruhi oleh tiga faktor, yaitu kebutuhan internal, sumber makanan dan lingkungan fisik. Kebutuhan internal dipengaruhi oleh faktor lapar dan produksi larva (Howard \& Tschinkle, 1980), sedangkan lingkungan fisik dipengaruhi oleh perubahan kelembaban, temperatur dan panjang hari (Porter \& Tschinkle, 1987). Suhu lingkungan merupakan faktor fisik yang berpengaruh secara langsung terhadap aktivitas pencarian makan. Semut rangrang mulai mencari makan saat suhu udara 23-30 ${ }^{\circ} \mathrm{C}$. Aktivitas diurnal semut rangrang lebih besar dibandingkan aktivitas nokturnalnya, yaitu antara pukul 15.00-19.00 adalah waktu yang paling banyak digunakan semut rangrang untuk mencari makan (Dejean, 1990 dalam Harlan, 2006).

\section{K E S I M P U L A N}

Berdasarkan hasil yang didapatkan, maka dapat disimpulkan bahwa pakan berupa keong mas dan cacing tanah dapat meningkatkan produksi jumlah dan bobot kroto dibandingkan dengan pakan berupa ampas tahu dan semut rangrang yang diberi pakan 
cacing tanah menghasilkan lebih banyak jumlah individu dan meningkatkan berat kroto semut rangrang.

\section{DAF TAR REFERENSI}

Agosti D, Majer D, Alonso LE, Schultz TR. 2000. Ants Standard Methods for Measuring and Monitoring Biodiversity. Washington: Smithsonian Institution Press.

Andersen AA. 1997. Using Ants as Bioindicators. Multiscale Issues in Ant Community Ecology. Page 8. Conservation Ecology.

Anderson AP, Mather, Richardson. 2004. Nutrition of the Mud Crab Scylla serrate (forskal), In Allan \& D. Fielder (Ed.). Proceeding and Southeast Asia.

Césard N. 2004. Harvesting and commercialisation of kroto (Oecophylla smaragdina) in the Malingping area, West Java, Indonesia. Jakarta. pp.61-77.

Chapman RF. 1998. The Insects: Structure and Function 4th editions. Australia: Cambridge University Press. p 69-72.

Duldjaman M. 2005. Kualitas Karkas Domba yang Diberi Pakan Rumput Kering dan ditambah Ampas Tahu. Fakultas Peternakan Institut Pertanian Bogor. Bogor. J.Indon. Trop.Anim.Agric. 30(20).

Falahudin I. 2012. Peranan Semut Rangrang (Oecophylla smaragdina) Dalam Pengendalian Biologis Pada Perkebunan Kelapa sawit. Palembang: Fakultas Tarbiyah IAIN Raden Fatah.

Harlan I. 2006. Aktivitas Pencarian Makan dan Pemindahan Larva Semut Rangrang Oecophylla smaragdina (formicidae: hymenoptera). [Skripsi]. Bogor: Jurusan Biologi, Fakultas MIPA IPB Bogor.

Holldobler BK, Wilson EO. 1977. Weaver Ants. These Social Insects Use Their Own Larvae as Shuttles to Weave Leaves into Large Nests in The Rain Forests of Africa and Asia. Their Behaviour is Coordinated by Complex Chemical Stimuli. Int J. Scientific American. 3: 146 - 154.

Howard DF, Tschinkle WR. 1980. Aspect of Necoporic in The Red Imported Fire Ant. . Florida: Departement of Biological Science. Florida State University.

Juriyanto. 2013. Untung Besar Budidaya Kroto dengan Aneka Metode Pengembangbiakan Semut Rangrang. Yogyakarta: Araska.

Kroto Research Institute. 2012. Metode Ternak http://semutkroto.com/visi-dan-misi/. [16 April 2016].
Mele PV, Nguyen TTC. 2007. Ants as Friends. Engham: CAB International

Mele PV, Cuc NTT. 2007. Ants as Friends: Improving your Tree Crops with Weaver Ants (2nd Edition). Cotonou, Benin, and CABI, Egham, UK: Africa Rice Center (WARDA). 72 pp

Mele PV. 2008. A historical review of research on the weaver ant Oecophylla in biological control. Agricultural and Forest Entomology. 10: 13-22.

Offenberg J, Wiwatwitaya D. 2010. Sustainable weaver ant (Oecophylla smaragdina) farming: harvest yields and effects on worker ant density. Asian Myrmecology. 3: 55-62.

Offenberg J, Thu CNT, Decha W. 2013. The Effectivess of Weaver Ant (Oecophylla smaragdina) Biocontrol in Southeast Asian Citrus and Mango. Asian Myrmecology. 5: 139-149.

Palungkun R. 1999. Sukses Beternak Cacing Tanah Lumbricus rubellus. Jakarta: Penebar Swadaya.

Porter SD, Tschinkle WR. 1987. Foraging in Solonepsis invica Effect on Weather ands Season. . Florida: Depertement of Biological Science. Florida State University.

Prasetyo DE. 2015. Peningkatan Produktivitas dan Kualitas Kroto Melalui Kombinasi Komposisi Pakan Semut Rangrang (Oecophylla smaragdina). [Skripsi]. Jember: Program Studi Agroteknologi, Fakultas Pertanian Universitas Jember.

Prayoga B. 2013. Kupas Tuntas Budidaya Kroto Cara Modern. Jakarta: Penebar Swadaya.

Prayoga B. 2014. Menjawab Teka-teki Beternak dan Berbisnis Kroto. Jakarta: Penebar Swadaya.

Rahman AR. 2015. Pemanfaatan Nutrisi Cair Terhadap Kualitas dan Waktu Panen Kroto Semut Rangrang (Oecophylla smaragdina). Jember: Fakultas Pertanian Universitas Jember.

Rizqytiasti A. 2015. Kultur Semut Rangrang (Oecophylla smaragdina) Secara Artifisial Menggunakan Beberapa Jenis Pakan Berbeda. [Skripsi]. Purwokerto: Fakultas Biologi, Universitas Jenderal Soedirman.

Salle AJ. 1973. Fundamental Principles of Bacteriology 7th Ed. Toronto: McGraw-Hill Book company.

Scott ML, Nesheim MC, Young RJ. 1982. Nutrition of the Chicken. New York: Scott, Ithaca. p. 119

Suhara. 2009. Semut Rangrang (Oecophylla smaragdina). Bandung: Jurusan Pendidikan Biologi. FMIPA. Universitas Pendidikan Indonesia. 